\section{Math Anxiety in Students With and Without Math Learning Difficulties}

\author{
Yılmaz Mutlu*
}

$\begin{array}{ll}\text { Received: } & \text { 08 January } 2019 \\ \text { Revised: } & 19 \text { March } 2019 \\ \text { Accepted: } & 15 \text { May } 2019 \\ \text { ISSN: 1307-9298 } \\ \text { Copyright @ IEJEE } \\ \text { www.iejee.com }\end{array}$

DOI: 10.26822/iejee.2019553343

\begin{abstract}
The aim of this study was to determine the dimensions of the relationship between math anxiety and mathematics achievement of the third grade students with and without mathematics learning difficulties. Data were collected from 288 elementary school students using math anxiety scale and math achievement test tools. The mathematics achievement test scores reveal that the students were classified into four groups: math learning difficulties (0-10\%), low achievers (11-25\%), normal achievers (26-95\%), and high achievers (96-100\%). The findings reveal that there was a strong correlation ( $r=-.597)$ between the math anxiety and math achievement of the participants, while there was no significant difference between the mean scores of the mathematics anxiety of the lower two groups as it was between the two upper groups. This indicates that the math anxiety level of the students with math learning difficulties does not differ from the low achievers. However, the results depict a significant difference between the mean scores of the math anxiety of the low achievers and the normal achievers.
\end{abstract}

Keywords: Math Anxiety, Working Memory, Mathematics Learning Difficulties, Dyscalculia

\section{Introduction}

The importance of mathematics in daily and professional life has been increasing with the contribution of developing technology. The level of the mathematical knowledge and skills directly influence the quality standards of our individual and social life. However, mathematics the importance of which we feel in every aspect of our life is unfortunately not learned enough by many individuals for many reasons. The leading reasons regarding this issue are as follows: the abstract and hierarchical structure of mathematics, methods and strategies in learning mathematics, and the learning difficulties in mathematics. Developmental Dyscalculia (DD)/Mathematics Learning Difficulty (MLD) is a brain-based condition that negatively affects mathematics acquisition (Piazza et al., 2010 ;von Aster \& Shalev 2007). The mathematical performance of a student with MLD is much lower than expected for age, intelligence, and education, although there are no conditions such as intellectual disability, emotional disturbances, cultural deprivation, and lack of education (Büttner \& Hasselhorn, 2011). Difficulties in mathematics result from a number of cognitive and emotional factors. The math anxiety is one of the emotional factors which may severely disrupt a significant number of children and adults of learning and achievement math (Dowker, Sarkar \& Looi, 2016).

The math anxiety is defined as "the feelings of tension and anxiety that interfere with the manipulation of numbers and the solving mathematical problems in a wide variety of ordinary life and academic situations" (Richardson \& Suinn, 1972 p. 551). Sherard (1981) describes the math anxiety as the fear of math or an intense and negative emotional response to mathematics. There are many reasons for the cause of the math anxiety. These include lack of the appropriate mathematical background of the students, study habits of memorizing formulas, problems and applications that are not related to real life, challenging and time limited exams, lack of concrete materials, difficulty of some subjects in mathemat- ics, type of personality, negative approach on mathematics, lack of confidence, the approaches, feelings, and thoughts of teachers and parents on mathematics (Ashcraft \& Ridley, 2005; Finlayson, 2014; Hoffman, 2010; Maloney, Ansari \& Fugelsang, 2011; Rubinsten \& Tannock, 2010).

The negative relationship between the math anxiety and math performance is an international issue. The PISA (Programme for International Student Assessment) statistics measuring a wide variety of countries and cultures depict that the high level of negative correlation between math anxiety and mathematical performance is remarkable (Foley et al., 2017). Some studies showed that highly math-anxious individuals worse than those with low mathematics anxiety in terms of solving mathematical problems (Ashcraft \& Kirk, 2001). These differences are not typically observed in simple arithmetic operations such as $7+9$ and $6 \times 8$, but it is more evident when more difficult arithmetic problems are tested (Ashcraft \& Kirk, 2001).

The math anxiety is associated with the cognitive information processing resources during arithmetic task performance in a developing brain (Young, Wu \& Menon, 2012). It is generally accepted that the math anxiety affects negatively the mathematical performance by distorting sources of working memory (Ashcraft \& Kirk, 2001; Beilock \& Carr, 2005; Young, Wu \& Menon, 2012). The working memory is conceptualized as a limited source of cognitive systems responsible for the temporary storage and processing of information in momentary awareness (Baddeley \& Hitch, 1994).

The learning difficulties in mathematics relate to deficiencies in the central executive component of the working memory (Geary, Hoard, Byrd-Craven, Nugent, \& Numtee, 2007; Passolunghi \& Siegel, 2004). Many studies suggest that individuals with learning difficulties in mathematics have lack of the working memory (Geary, Hoard, Byrd-Craven, \& DeSoto, 2004; Wilson \& Swanson, 2001). It is stated that students 
with learning difficulties in mathematics use more inferior strategies than their peers for solving basic $(4+3)$ and complex $(16+8)$ addition, and fall two years behind of their peers while they fall a year behind in their peers' working memory capacities (Geary, Hoard, Byrd-Craven, \& DeSoto, 2004).

Highly math-anxious individuals showed smaller working memory spans, especially when evaluated with a computationally based task. This reduced working memory capacity, when implemented simultaneously with a memory load task, resulting in a significant increase in the reaction time and errors (Ashcraft \& Kirk, 2001). A number of studies showed that working memory capacity is a robust predictor of arithmetic problem solving and solution strategies (Geary, Hamson, \& Hoard, 2000; De Smedt et al., 2009; Passolunghi, Vercelloni, \& Schadee, 2007).

Although it is not clear to what extent the math anxiety affects the mathematical difficulties and how much of the experience of mathematical difficulties cause mathematical anxiety, there is considerable evidence that math anxiety affects the mathematical performance that requires working memory (Dowker et al., 2016). Figure 1 below depicts these reciprocal relationships among math anxiety, poor math performance, and lack of working memory. The findings of the studies mentioned above, make it possible to draw this figure.

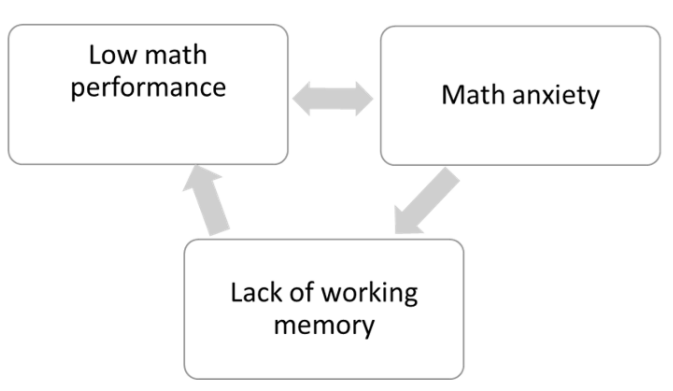

Figure 1. The relationships among poor mathematical performance, math anxiety, and working memory

Basic numerical and mathematical skills have been crucial predictors of an individual's vital success. When anxiety is controlled, it is seen that the mathematical performance of the students increases significantly (Kamann, Wong 1993; Maloney \& Beilock 2012). Hence, early identification and treatment of the math anxiety is of importance. Otherwise, early anxieties can have a snowball effect and eventually lead students to avoid mathematics courses and career options for math majors (Ramirez et al., 2013). Although many studies (Harari, Vukovic, \& Bailey, 2013; Mutlu, Söylemez, \& Yasul, 2017; Krinzinger, Kaufmann, \& Willmes, 2009; Vukovic, Kieffer, Bailey, \& Harari, 2013;) confirm that math anxiety is present at high levels in primary school children, it is seen that the studies conducted at this level are relatively less when the literature of math anxiety is examined. In this context, this study aims to determine the dimensions of the relationship between math anxiety and mathematics achievement of third graders by their mathematics achievement levels.

\section{Methods}

The study was conducted by descriptive method. The purpose of the descriptive method is to reveal an existing situation as it is. This study aims to examine the relationship between math anxiety and mathematics achievement of third graders in primary school in terms of the student achievement levels.

\section{Participants}

Researchers of mathematics learning difficulties (MLD) commonly use cutoff scores to determine which participants have MLD. These cutoff scores vary between -2 ss and -0.68 ss (Devine, Soltesz, Nobes, Goswani and Szucs, 2013). Some researchers apply more restrictive cutoffs than others (e.g., performance below the 10th percentile or below the $35^{\text {th }}$ percentile) (Murphy et al. 2007). The present study adopted the math achievement test (Fidan, 2013) to determine children with MLD based below the 10th percentile. The unit of analysis was third graders of an elementary school located in a low socioeconomic area. The study reached 288 students using math anxiety scale and math achievement test tools. The students were classified into four groups by their mathematics achievement test scores: math learning difficulties (0-10\%), low achievers (11-25\%), normal achievers (26-95\%), and high achievers (96-100\%).

Table 1. Distribution of participants by gender and groups

\begin{tabular}{|c|c|c|c|}
\hline \multirow{2}{*}{ Groups } & \multicolumn{2}{|c|}{ Gender } & \multirow{2}{*}{ Total } \\
\hline & Boys & Girls & \\
\hline MLD & 20 & 9 & 29 \\
\hline LA & 21 & 22 & 43 \\
\hline NA & 102 & 99 & 201 \\
\hline $\mathrm{HA}$ & 5 & 10 & 15 \\
\hline Total & 148 & 140 & 288 \\
\hline
\end{tabular}

\section{Data Collection Tools}

Two copyrighted survey scales, consisting of 29 items were used to construct a survey questionnaire. The first scale is the Math Anxiety Scale developed by Mutlu \& Söylemez (2017) for $3^{\text {rd }}$ and $4^{\text {th }}$ graders with a 3-factor structure of 13 items. The Cronbach's Alpha coefficient is adopted by the study to evaluate the extent to which a measurement produces reliable results at different times. The Cronbach Alpha coefficient of the scale is .75 which confirms the reliability of and internal consistency of the study. The response set was designed in accordance with the threepoint Likert scale with agree, neutral, and disagree. Of the 13 items in the scale, 5 were positive and 8 were negative. Positive items were rated as 3-2-1, while negative items were rated as 1-2-3. The highest score on the scale was 39 and the lowest on the scale was 13.

The second data collection tool adopted by this study is the math achievement test for third graders developed by Fidan (2013). It has 16 items designed in accordance with the national math curriculum. Correct responses were scored one point while wrong responses were scored zero point.

\section{Data Analysis}

The study mainly utilized five statistical analyses which are descriptive analysis, independent samples $t$-test, Pearson product-moment correlation analysis, linear regression and ANOVA. First, an independent samples $t$-test was performed to determine whether there was a significant difference between the levels of math anxiety by gender. Then, a Pearson product-moment correlation analysis was performed to determine the relationship between the math anxiety and mathematics achievement of the students. After that, a linear regression analysis was performed to predict mathematics achievement of the participants based on the math anxiety. Finally, an ANOVA was performed to determine if there was a significant difference between the math anxiety of the groups determined in terms of mathematics achievement. 


\section{Results}

The findings of the math anxiety scores by gender of the study found no significant difference between the averages $[t(286)=1.790, p<.05]$. This result shows that the math anxiety levels of girls and boys are close to each other. Since there is no difference between math anxiety scores by gender, the data in the study were combined.

Table 2. Comparison of anxiety scores by gender

\begin{tabular}{lrrrrrr}
\hline Gender & $N$ & $M$ & $S d$ & $d f$ & $t$ & $p$ \\
\hline Girls & 148 & 1.55 & 0.38 & 7 & & \\
\hline Boys & 140 & 1.47 & 0.37 & 7 & & .075 \\
\hline
\end{tabular}

There was a strong and negative correlation between math anxiety and mathematics achievement with the values of $r=-0.597, n=288$, and $p=.00$. This result indicates that the highly math-anxious students and decreases in math anxiety were correlated with increases in rating of math achievement.

A simple linear regression was calculated to predict math achievement level based on the math anxiety. A significant regression equation was found $\left(F_{(1,286)}=158.691, p<.000\right)$ with an $R^{2}$ of .357. Participants' predicted math achievement is equal to $20.153+-6.611$ when math anxiety is measured in unit. Math achievement decreased -6.611 for each unit of the math anxiety.

Figure 1 below shows the relationship between the math anxiety of the children and their mathematics achievement on a group basis. Figure 1 provides us that there is a negative correlation between mathematical performance and math anxiety. The results depict that the HA group has the lowest math anxiety score, while the MLD group has the highest math anxiety.

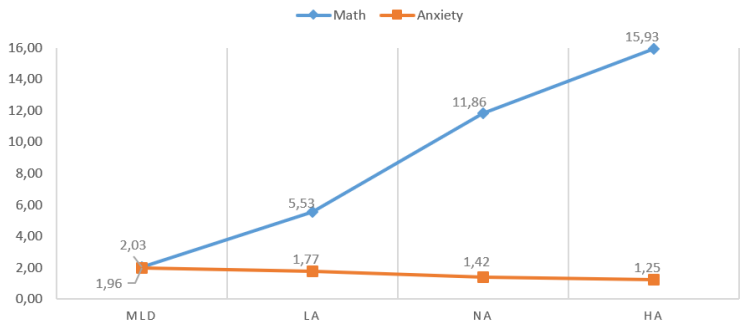

Figure 2. Group's math and math anxiety scores

Table 3. Comparison of the mathematical anxiety scores of the groups

\begin{tabular}{lrrrrrr}
\hline & $\begin{array}{r}\text { Sum of } \\
\text { Squares }\end{array}$ & $d f$ & $\begin{array}{r}\text { Mean } \\
\text { Square }\end{array}$ & $F$ & $p$ \\
\cline { 1 - 4 } Between Groups & 11.558 & 3 & 3.853 & & \\
\cline { 1 - 4 } Within Groups & 29.907 & 284 & .105 & 36.584 & .000 \\
\cline { 1 - 4 } Total & 41.464 & 287 & & & \\
\cline { 1 - 3 }
\end{tabular}

The table indicates that there is a statistically significant difference between groups as determined at the $p<.05$ level by one-way ANOVA $\left(F_{(3,284)}=36.584, p=.000\right)$. Post hoc comparisons using the Tukey test indicated that the mean score for MLD group $(M=1.96, s d=0.30)$ was significantly different than the NA group $(M=1.41, s d=0.84)$ and $\mathrm{HA}$ group $(M=1.24, s d=0.28)$. However, the MLD group $(M=$ $1.96, s d=0.30)$ did not significantly differ from the LA $\operatorname{group}(M=1.76, s d=0.27)$.

\section{Discussion and Conclusion}

Math anxiety is a problem that can affect adversely the academic success and employment prospects of the chil- dren. Although the literature on math anxiety is largely focused on adults, recent studies have reported that some children begin to encounter the math anxiety at the elementary school level. (Krinzinger, Kaufmann \& Willmes, 2009; Harari, Vukovic \& Bailey, 2013; Mutlu, Söylemez \& Yasul, 2017). The findings of the study depict that the correlation level of math anxiety and math achievement is -.597 among students. In a meta-analysis study of Hembre (1990) and Ma (1999), found that the level of relationship between mathematical success and math anxiety is -.34 and -.27 , respectively. In a similar meta-analysis study performed in Turkey, the correlation coefficient was found to be -.44 (Sad, Kis, Demir, \& Özer, 2016). The different occurrence of the coefficients is probably dependent on the scales used and the sample variety.

The participants of the study were classified into four groups: math learning difficulties (0-10\%), low successful (11-25\%), normal (26-95\%), and high successful (96-100\%) by the mathematics achievement test scores. The study compared the math anxiety scores of the groups and found no significant difference between the mean scores of the math anxiety of the lower two groups (mean of MLD math anxiety, .196; mean of LA math anxiety .177) as it was between the upper two groups (mean of NA math anxiety, .142; mean of HA math anxiety .125). This indicates that the math anxiety level of the students with learning difficulties in math does not differ from the low math students. However, a significant difference was found between the mean scores of math anxiety of the low successful and the normal group.

It may be better for some students to maintain moderate levels of math anxiety, for making their learning and testing materials moderately challenging (Wang et al. 2015) but it can be clearly said that high math anxiety has detrimental effects on the mathematical performance of the individuals. Especially for students with learning difficulties in math, the high level of math anxiety will lead to destructive effects in many dimensions, primarily lack of working memory.

Many of the techniques employed to reduce or eliminate the link between the math anxiety and poor math performance involve addressing the anxiety rather than training math itself (Maloney \& Beilock 2012). Some methods for reducing math anxiety can be used in teaching mathematics. For instance, effective instruction for struggling mathematics learners includes instructional explicitness, a strong conceptual basis, cumulative review and practice, and motivators to help maintain student interest and engagement (Fuchs et al., 2008; Gersten et al., 2009).

\section{References}

Ashcraft, M. H., \& Kirk, E. P. (2001). The relationships among working memory, math anxiety, and performance. Journal of Experimental Psychology: General, 130(2), 224-237. DOI: 10.1037//0096-3445.130.2.224.

Ashcraft, M. H., \& Ridley, K. S. (2005). Math anxiety and its cognitive consequences: A tutorial review. J. I. D. Campbell (Ed.), Handbook of Mathematical Cognition (pp. 315-327). New York: Psychology Press.

Baddeley, A. D., \& Hitch, G. J. (1994). Developments in the concept of working memory. Neuropsychology, 8 , 485-493.

Beilock, S. L., \& Carr, T. H. (2005). When high-powered people fail. Working memory and "choking under pressure" in math. Psychological science, 16(2), 101-105. DOI: 10.1111/j.0956-7976.2005.00789.x. 
Büttner, G., \& Hasselhorn, M. (2011). Learning disabilities: Debates on definitions, causes, subtypes, and responses. International Journal of Disability, Development and Education, 58(1), 75-87.

De Smedt, B., Janssen, R., Bouwens, K., Verschaffel, L., Boets, B., \& Ghesquière, P. (2009). Working memory and individual differences in mathematics achievement: A longitudinal study from first grade to second grade. Journal of Experimental Child Psychology, 103(2), 186-201. doi:10.1016/j. jecp.2009.01.004

Devine,A., Soltesz, F., Nobes, A., Goswani, U. ve Szucs, D. (2013). Gender differences in developmental dyscalculia depend on diagnostic criteria. Learning and Instruction, 27, 31-39.

Dowker, A., Sarkar, A., \& Looi, C. Y. (2016). Mathematics anxiety: What have we learned in 60 years?. Frontiers in psychology, 7, 1-16. DOI: 10.3389/ fpsyg.2016.00508.

Fidan, E. (2013). ilkokul öğrencileri için matematik dersi sayılar öğrenme alanında başarı testi geliştirilmesi (Yayımlanmamış Yüksek Lisans Tezi). Ankara Üniversitesi, Eğitim Bilimleri Enstitüsü.

Finlayson, M. (2014). Addressing math anxiety in the classroom. Improving Schools, 17(1), 99-115.

Fuchs, L. S., Fuchs, D., Powell, S. R., Seethaler, P. M., Cirino, P. T., \& Fletcher, J. M. (2008). Intensive intervention for students with mathematics disabilities: Seven principles of effective practice. Learning Disability Quarterly, 31, 79-92. http:// dx. doi.org/10.2307/20528819

Foley, A. E., Herts, J. B., Borgonovi, F., Guerriero, S., Levine, S. C., \& Beilock, S. L. (2017). The Math Anxiety-Performance Link. Current Directions in Psychological Science, 26(1), 52-58. DOI: 10.1177/0963721416672463.

Geary, D. C., Hamson, C. O., \& Hoard, M. K. (2000). Numerical and arithmetical cognition: A longitudinal study of process and concept deficits in children with learning disability. Journal of Experimental Child Psychology, 77(3), 236-263. doi:10.1006/ jecp.2000.2561

Geary, D. C. (2004). Mathematics and learning disabilities. Journal of learning disabilities, 37(1), 4-15.

Geary, D. C., Hoard, M. K., Byrd-Craven, J., ve DeSoto, M. C. (2004). Strategy choices in simple and complex addition: Contributions of working memory and counting knowledge for children with mathematical disability. Journal of experimental child psychology, 88(2), 121-151.

Geary, D. C., Hoard, M. K., Byrd-Craven, J., Nugent, L., \& Numtee, C. (2007). Cognitive mechanisms underlying achievement deficits in children with mathematical learning disability. Child Development, 78(4), 1343-1359. doi:10.1111/j.1467-8624.2007.01069.x

Gersten, R., Chard, D., Jayanthi, M., Baker, S., Morphy, P., \& Flojo, J. (2009). Mathematics instruction for students with learning disabilities: A meta-analysis of Instructional Components. Review of Educational Research, 79(3), 1202-1242. Retrieved from http:// www.jstor.org/stable/40469093
Harari, R. R., Vukovic, R. K., \& Bailey, S. P. (2013). Mathematics anxiety in young children: an exploratory study. The Journal of Experimental Education, 81(4), 538-555.

Hembree, R. (1990). The nature, effects, and relief of mathematics anxiety. Journal for Research in Mathematics Education, 21(1), 33-46.

Hoffman, B. (2010). "I Think I Can, but I'm Afraid to Try": The role of self-efficacy beliefs and mathematics anxiety in mathematics problem-solving efficiency. Learning and Individual Differences, 20(3), 276-283.

Kamann, M. P., \& Wong, B. Y. (1993). Inducing adaptive coping self-statements in children with learning disabilities through self-instruction training. Journal of Learning Disabilities, 26(9), 630-638. DOI: $10.1177 / 002221949302600913$.

Krinzinger, H., Kaufmann, L., \& Willmes, K. (2009). Math Anxiety and math ability in early primary school years. Journal of Psychoeducational Assessment, 27(3), 206225. http://doi.org/10.1177/0734282908330583.

Ma, X. (1999). A meta-analysis of the relationship between anxiety toward mathematics and achievement in mathematics. Journal for Research in Mathematics Education, 30(5), 520-540.

Maloney, E. A., \& Beilock, S. L. (2012): Math anxiety. Who has it, why it develops, and how to guard against it. Trends in Cognitive Sciences, 16(8), 404-406. DOI: 10.1016/j.tics.2012.06.008.

Maloney, E. A., Ansari, D. \& Fugelsang, J. A. (2011). Rapid Communication. The effect of mathematics anxiety on the processing of numerical magnitude. The Quarterly Journal of Experimental Psychology, 64(1), 10-16.

Murphy, M. M., Mazzocco, M. M., Hanich, L. B., \& Early, M. C. (2007). Cognitive characteristics of children with mathematics learning disability ( $\mathrm{mld}$ ) vary as a function of the cutoff criterion used to define MLD. Journal of Learning Disabilities, 40(5), 458-478. https://doi.org/10.1177/00222194070400050901

Mutlu, Y., Söylemez, İ., \& Yasul, A. F. (2017). ìlkokul öğrencilerinin matematik kaygısı ile matematik başarıları arasındaki ilişkinin incelenmesi. Journal of $\mathrm{Hu}$ man Sciences, 14(4), 4425-4434. doi:10.14687/jhs. v14i4.5019

Mutlu, Y.\& Söylemez, İ. (2018). illkokul 3. ve 4. sınıf çocukları için matematik kaygı ölçeği; Güvenirlik ve geçerlik çalışması. EKEV Akademi Dergisi, 22(73), 429-440.

Ramirez, G., Gunderson, E. A., Levine, S. C., Beilock, S. L. (2013). Math anxiety, working memory, and math achievement in early elementary school. Journal of Cognition and Development 14(2), 187-202. DOI: 10.1080/15248372.2012.664593.

Richardson, F. C. \& Suinn, R. M. (1972). The mathematics anxiety rating scale: Psychometric data. Journal of Counseling Psychology, 19(6), 551-554.

Rubinsten, O. \& Tannock, R. (2010). Mathematics anxiety in children with developmental dyscalculia. Behavioral and Brain Functions, 6(1), 46-58. 
Passolunghi, M. C., \& Siegel, L. S. (2004). Working memory and access to numerical information in children with disability in mathematics. Journal of Experimental Child Psychology, 88(4), 348- 367. doi:10.1016/j.jecp.2004.04.002

Passolunghi, M. C., Vercelloni, B., \& Schadee, H. (2007). The precursors of mathematics learning: Working memory, phonological ability and numerical competence. Cognitive Development, 22(2), 165-184. doi:10.1016/j.cogdev.2006.09.001

Piazza, M., Facoetti, A., Trussardi, A. N., Berteletti, I., Conte, S., Lucangeli, D., \& Zorzi, M. (2010). Developmental trajectory of number acuity reveals a severe impairment in developmental dyscalculia. Cognition 116(1), 33-41.

Sherard, Wade H. (1981). Math anxiety in the classroom. The Clearing House: A Journal of Educational Strategies, Issues and ldeas, 55(3), 106-110.

Von Aster, M. G., \& Shalev, R. S. (2007). Number development and developmental dyscalculia. Developmen tal Medicine \& Child Neurology, 49(11), 868-873.

Vukovic, R. K., Kieffer, M. J., Bailey, S. P., \& Harari, R. R. (2013). Mathematics anxiety in young children. Concurrent and longitudinal associations with mathematical performance. Contemporary Educational Psychology, 38(1), 1-10. DOI: 10.1016/j. cedpsych.2012.09.001.

Wang, Z., Lukowski, S. L., Hart, S. A., Lyons, I. M., \& Thompson, L. A.; Kovas, Y. (2015). Is math anxiety always bad for math learning? The role of math motivation. Psychological Science, 26(12), 1863-1876. DOI: $10.1177 / 0956797615602471$.

Wilson, K. M., \& Swanson, H. L. (2001). Are mathematics disabilities due to a domain-general or a domain-specific working memory deficit? Journal of Learning Disabilities, 34(3), 237-248.

Young, C. B., Wu, S. S., Menon, V. (2012). The neurodevelopmental basis of math anxiety. Psychological Science, 23(5), 492-501. DOI: 10.1177/0956797611429134. 